\title{
ISLAH MENURUT HUKUM ISLAM RELEVANSINYA DENGAN PENEGAKAN HUKUM PIDANA DI TINGKAT PENYIDIKAN
}

\author{
Waluyadi \\ Fakultas Hukum Universitas Swadaya Gunung Jati (Unswagati) Cirebon \\ Email: Waluyadi_68@yahoo.com
}

\begin{abstract}
The purpose of this reseach is to describe the reality of peace at investigation levels, then compared to islah according to Islamic law as the reason of criminal removing, to find / to know the relevance. Based on the relevance, it possible become material for the legislators to formulate islah as a model of law enforcement at the level of investigation. This research is the normative research supported by empirical research. The data used was primary and secondary data. Data was collected by means of study documentation and interviews. Data were analyzed quatitatively dan and presented quatitatively. The research showed that the completion of criminal case based on the agreement between perpetrator and victim, along the case have not reached the judge. If the agreement is violated, they agreed to use the formal law. Criminal case which are resolved with peace/islah personalized and value of the loss is relatively small. Islam placing islah as an alternative the completion of criminal matters, along the case have not reached the judge. In the literature and practice, settling disputes with peace known as Alternative Dispute Resolution (ADR), which is based on Restorative Justice Theory. Al Qur'an has set peace/islah as a model the completion of criminal matters, long before these theories arises. Peace/ islah in the completion of a criminal case at the level of investigation relevant to satisfy the principle of fast, simple, and inexpensive.
\end{abstract}

Keyword : Islah, Islamic Law, Relevance and Investigation

\begin{abstract}
Abstrak
Tujuan penelitian ini adalah mendeskripsikan realitas perdamaian pada tingkat penyidikan, selanjutnya akan dibandingkan dengan islah menurut hukum Islam sebagai alasan penghapus pidana, untuk diketahui/ ditemukan relevansinya. Berdasarkan relevansi tersebut, dimungkinkan menjadi bahan bagi pembentuk undang-undang untuk menformulasikan islah sebagai model penegakan hukum pidana pada tingkat penyidikan. Penelitian ini merupakan penelitian normatif yang didukung dengan penelitian empiris. Data yang digunakan mencakup data primer dan data sekunder. Teknik pengumpulan data dilakukan dengan cara studi dokumentasi dan wawancara. Data dianalisis secara kualitatif dan disajikan secara deskriptif. Hasil penelitian menunjukan penyelesaian perkara pidana dengan perdamaian pada tingkat penyidikan mendasarkan kesepakatan pelaku dan korban. Apabila kesepakatan itu dilanggar, mereka sepakat untuk menggunakan hukum formal. Perkara pidana yang diselesaikan dengan perdamaian/ islah, bersifat personal dan nilai kerugiannya relatif kecil. Islam menempatkan perdamaian/islah sebagai alternatif penyelesaian perkara pidana, sepanjang perkara tersebut belum sampai ke tangan hakim. Dalam literatur dan praktik, penyelesaian perkara dengan perdamaian disebut Alternative Disput Resolution (ADR) yang mendasarkan pada teori Restorative Justice. Al-Qur'an telah menetapkan Perdamaian/ Islam sebagai model penyelesaian perkara pidana, jauh sebelum teori-teori itu muncul. Perdamaian/ Islah dalam penyelesaian perkara pidana ditingkat penyidikan, relevan untuk pemenuhan asas cepat, sederhana dan biaya ringan.
\end{abstract}

Kata Kunci: Islah, Hukum Islam, Relevansi dan Penyidikan

\section{A. Pendahuluan}

Berkerjanya Sistem Peradian Pidana (SPP) sebagai landasan penyelesaian kasus pidana, hanya mampu melahirkan kepastian hukum (legal justice) dan belum memberikan keadilan. SPP gagal memberikan mewujudkan keadilan yang substansial (Muhammad Taufik: 2013: 22). Berhukum hendaknya untuk keadilan dan bukan hanya untuk hukum (Al-Qur'an, Al-Ma'idah: 8). 
Menurut Marc Galantar, membicarakan akses pengadilan semata-mata mengharuskan rakyat membawa persoalannya ke pengadilan, ini adalah terlalu sempit. Pengadilan harus diperluas sehingga mencakup sejumlah variasi badan-badan yang juga melakukan penyelesaian masalah/remedial agencies". (Satjipto Rahardjo: 2010: 240).

Selama ini, hukum hanya ditegakkan melalui mekanisme "mesin robot". Penegakan hukum hanya ditempatkan sebagai alat untuk melaksanakan rumusan norma hukum yang ada dengan mengabaikan nurani. Melihat output penegakan hukum yang hanya melahirkan kepastian hukum (legal justice), penggunaan pendekatan sosiologis seharusnya sudah menjadi pilihan utama (Nurhasan Ismail: 2012: 7).

Sebagai konsekuensi logis pemberlakuan doktrin/paham legalistik formalistik, penentuan dapat atau tidaknya suatu perbuatan dipidana dan prosedur beracara, legalitasnya ditentukan oleh undang-undang. Kitab Undang-Undang Hukum Acara Pidana (KUHAP), tidak memberikan tempat bagi korban dan pelaku untuk menentukan sikap atas tindak pidana yang terjadi, termasuk melakukan perdamaian/islah. Posisi korban dalam KUHAP, hanya diperankan sebagai saksi korban sebagai bagian keterangan saksi yang merupakan alat bukti.

Keberadaan KUHAP yang merupakan pengganti dari Herzein Inlandsch Reglement (HIR), tidak menempatkan perlindungan korban sebagaimana mestinya. Kitab Undang-Undang Hukum Acara Pidana (KUHAP), hanya menjamin perlindungan hak asasi manusia (pelaku tindak pidana) dan jaminan objektifitas kekuasaan peradilan (juga untuk kepentingan pelaku), sementara korban tetap dalam posisi lemah

Kitab Undang-Undang Hukum Pidana (KUHP), tidak memberikan tempat bagi korban. Secara normatif, keberadaan KUHP memang dapat dipertanggungjawabkan, akan tetapi secara sosiologis, keberadaannya menimbulkan masalah. Hal ini dapat dipahami, oleh karena KUHP yang sekarang berlaku di Indonesia tidak berakar dari nilai-nilai dan norma asli Indonesia.

Pemberian maaf kepada pelaku tidak pidana oleh korban dan permintaan maaf pelaku kepada korban, merupakan bentuk pengabdian seorang mahluk kepada khaliq-Nya, yang pengaturannya sudah ditentukan dalam AlQur'an dan Hadis. Al-Qur'an melegalkan korban kejahatan untuk melakukan pembalasan kepada pelaku. Sungguhpun demikian, memaafkan dan mengadakan perdamaian, lebih mulia dari pada melakukan pembalasan (Al-Qur'an, Asy-Syuuraa: 40). Mengacu pada Al-Qur'an, Asy-Syuuraa': 40, menurut hukum Islam, penyelesaian kasus pidana dapat dilakukan melalui pengadilan dan di luar pengadilan.

Memposisikan kembali korban tindak pidana sebagai subyek hukum dapat dilakukan dengan cara melegalkan mereka untuk menentukan diproses atau tidaknya pelaku kejahatan. Harapan yang demikian harus dianggap sebagai sesuatu yang logis, oleh karena korbanlah yang merasakan akibat langsung tindak pidana.

Menurut hukum Islam, memberikan maaf baik diminta maupun tidak diminta dapat dilakukan setiap saat. Meminta maaf, dapat dilakukan setelah seseorang menyadari telah bersalah kepada orang lain. Dalam penegakan hukum, perdamaian/ islah seyogyanya dilakukan pada saat perkara sudah pada tingkat penyidikan. Dasar pertimbanganya adalah, pada saat itu sudah dapat diketahui salah ataun tidaknya seseorang yang disangka.

Pengalternatifan perdamaian//slah pada tahapan penyidikan, bukan berarti menutup kemungkinan dilakukannya Islah pada tahapan lain, seperti tahap penuntutan dan tahap pemeriksaan pengadilan. Perdamaian/Islah yang dilakukan pada tingkat penyidikan, dimaksudkan sebagai upaya meminimalisasi lamanya proses hukum setelah itu, yang dalam proses tersebut dimungkinkan menimbulkan ketidakadilan.

Pihak-pihak yang merasakan akibat dan juga berhubungan dengan tindak pidana adalah korban dan pelaku. Apabila demikian halnya, mengapa pelaku dan korban tidak diberi peran dalam penyelesaian tindak pidana, termasuk di dalamnya berdamai/berislah dan kemudian diakui dan diakomodasi oleh Undang-Undang sebagai alasan penghapus pidana. Mengacu pada pemahaman yang demikian, maka menarik untuk dikaji lebih lanjut tentang apakah penegakan hukum pidana di tingkat penyidikan dapat dilakukan dengan perdamaian dan bagaimanakah relevansi perdamaian pada tingkat penyidikan dengan Islah menurut hukum Islam. Berdasarkan relevansi tersebut, dimungkinkan menjadi bahan bagi pembentuk undang-undang untuk memformulasikan perdamaian/islah sebagai model penegakan hukum pidana pada tingkat penyidikan.

\section{B. Metode Penelitian.}

Tulisan ini merupakan hasil penelitian hukum normatif/doktrinal. Data yang digunakan mencakup data sekunder sebagai data utama dan 
data primer sebagai penunjang. Data sekunder berasal dari studi kepustkaan dan dokumentasi. Data primer bersumber dari hasil wawancara terbuka dengan para penyidik di wilayah hukum Polres cirebon Kota, Polres cirebon Kabupaten, Polres Kuningan, Polres Indramayu dan Polres Majalengka. Data yang diperoleh selanjutnya dianalisis secara kualitatif dan disajikan secara deskriptif.

\section{Hasil Penelitian dan Pembahasan.}

1. Jenis tindak pidana yang dapat diselesaikan dengan perdamaian di tingkat penyidikan.

Berdasarkan surat pernyataan bersama antara pelaku dan korban, jenis tindak pidana yang diselesaikan dengan perdamaian meliputi: 1. Kekerasan Dalam Rumah Tangga/ KDRT (Pasal 5 dan Pasal 44 UU No. 23 Tahun 2004); 2. Sengketa konsumen (Pasal 62 ayat (1) UU No. 8 Tahun 1999); 3. Penipuan (Pasal 378 KUHP); 4. Penggelapan (Pasal 372 KUHP); 5. Pengeroyokan di muka umum (Pasal 170 KUHP); 6. Penganiayaan ringan (Pasal 352 KUHP); 7. Pemalsuan (Pasal 266 KUHP); 8. Perbuatan cabul (Pasal 290-293 KUHP); 9. Pencurian biasa (Pasal 362); 10. Pencurian dengan pemberatan (Pasal 363 KUHP); 11. Perzinahan (Pasal 284 KUHP); 12. Penghinaan (Pasal $310 \mathrm{KUHP}) ; 13$. Pengerusakan (Pasal $406 \mathrm{KUHP}$ ); 14. Pencurian dengan dengan kekerasan (Pasal 365 KUHP); 15. Penganiayaan (Pasal 351 KUHP), 16. Perbuatan tidak menyenangkan (Pasal 335 KUHP); 17. Fitnah (Pasal 311 KUHP); 18. Perbuatan cabul (Pasal 289 KUHP); 19. Melarikan anak di bawah umur (Pasal 332 KUHP); dan 20. Menikah tanpa pasangan yang syah (Pasal 279 KUHP).

Berdasarkan uraian di atas diketahui, 20 tindak pidana yang diselesaikan dengan cara perdamaian/islah pada tingkat penyidikan 18 diantaranya adalah tindak pidana yang diatur dalam Kitab Undang-Undang Hukum Pidana (KUHP). IS Susanto menyebutnya sebagai kejahatan "warungan","tradisional" dan "primitif", yang cara penilainya menjadi kajian kriminologi klasik. Dalam perspektif kriminologi klasik kejahatan di definisikan setiap perbuatan yang dilarang oleh undangundang pidana dan penjahat adalah setiap orang yang melakukan kejahatan. (IS. Susanto: 2011: 6). Mengacu pada pemahaman yang demikian, maka seseorang dianggap jahat bukan karena ia jahat, akan tetapi undang- undang yang menetapkan bahwa seseorang itu jahat. Boleh jadi, perbuatan tertentu menurut penilaian masyarakat tidak jahat tetapi oleh undang-undang disebut jahat, demikian juga sebaliknya.

Kejahatan yang diselesaikan dengan perdamaian bersifat personal, terjadi antara individu, kerugianya bersifat personal dan nilai kerugianya relatif kecil. Apabila antara pelaku dan korban sudah damai/islah, pelaku bersedia memenuhi hak korban dan korban sudah memaafkan pelaku yang diwujudkan dengan akta perdamian, maka tujuan berhukum sudah tercapai. Apabila tujuan berhukum telah tercapai, maka pemaksaan penegakan hukum negara kepada warga negara dengan segala formalitasnya akan menjadi sia-sia.

Dilihat dari hukum materiil dan prosedur beracara, penyelesaian kasus pidana dengan pedamaian/Islah pada tingkat penyidikan sebagaimana tersebut di atas, dapat dikelompokan menjadi 3 (tiga) katagori. Kategori pertama, penyelesaian dengan perdamaian/islah yang secara limitatif Undang-Undang memungkinkan untuk itu. contohnya adalah penyelesaian sengketa konsumen. Kategori yang kedua, penyelesaian kasus pidana dengan cara perdamaian/islah ditingkat penyidikan dan Undang-Undang atau pasal yang tertentu hanya menyebutkan sebagai delik aduan. contohnya adalah penyelesaian kasus Kekerasan Dalam Rumah Tangga/KDRT dan perzinahan.

Kategori yang ketiga, penyelesaian kasus pidana dengan perdamaian/ islah di tingkat penyidikan dan tindak pidana itu tidak mengisyaratkan tentang kebolehan untuk diselesaikan dengan perdamaian/ islah dan bukan termasuk delik aduan. Penyelesaian model islah/perdamaian tersebut mendasarkan pada inisiatif kesepakatan antara pelaku dan korban.

2. Peran Polisi, Pelaku, korban dan pihak lain dalam Penyelesaian Kasus Pidana dengan Perdamaian pada tingkat Penyidikan.

Pekerjaan Polisi merupakan pekerjaan yang paling menarik untuk di perbincangkan. Polisi dilambangkan sebagai hukum yang hidup. Di tangan Polisilah hukum pidana mengalami perwujudanya. Apabila hukum bertujuan menciptakan ketertiban dalam masyarakat diantaranya melawan kejahatan, maka ditangan Polisilah penentuan tentang penegakan ketertiban, pihak-pihak yang 
mesti ditundukan dan pihak-pihak yang harus di lindungi. Berdasarkan sifat pekerjaanya itulah, Polisi banyak berhubungan dengan masyarakat, sehingga rentan atas penilaian masyarakat (Sajtipto Rahardjo: 2011: 111)

Suteki (Suteki: 2013: tanpa halaman) menggambarakan kehidupan polisi sebagai gambaran yang complex dan complicated, sehingga ilmu yang dibutuhkan bersifat interdispliner. Dalam kedudukanya sebagai in optima forma dalam criminal justice system, polisi adalah garda paling depan yang seharusnya mampu bertindak sebagai hukum yang hidup. Pekerjaan polisi sering disebut sebagai pekerjaan yang berlumuran noda (fainted accupation)

Dalam penyelesaian perkara pidana dengan cara islah/perdamaian, peran Polisi adalah memfasilitasi penyelesaian kasus tersebut. Peran pelaku dan korban adalah melakukan musyawarah untuk mencapai mufakat. Dalam dalam pelaksanaan penyelesaian kasus pidana dengan cara perdamaian/islah juga melibatkan anggota keluarga, baik dari pihak korban maupun pelaku, saksi baik dari pihak korban dan pelaku serta tokoh masyarakat.

Korban berhak menerima atau menolak permohonan korban untuk berdamai. Apabila permohonan pelaku diterima oleh korban, pelaku harus memenuhi persyaratan yang disampaikan oleh korban. Peran pihak lain adalah sebagai saksi dan mengusahakan pengupayaan perdamaian. Polisi akan memberi kesempatan kepada pelaku, korban dan juga pihak yang terkait untuk bermusyawarah secara mufakat. Korban sebagai pelapor berhak menentukan diterima atau tidaknya penawaran penyelesaian kasus pidana dengan cara perdamaian, yang ditawarkan oleh pelaku.

Polisi akan menerima laporan/pengaduan, meminta keterangan korban dan saksi-saksi dan melakukan pemanggilan terhadap pelaku untuk diminta keteranganya. Korban membuat laporan/pengaduan, memberikan keterangan agar perkaranya di tindaklanjuti serta kerugiannya dapat dikembalikan. Dalam kasus kejahatan tehadap harta, pelaku harus memenuhi panggilan penyidik untuk memberikan keterangan, bertanggungjawab untuk mengembalikan harta milik korban serta meminta korban agar perkaranya tidak dilanjutkan ke Pengadilan.

Esensi peraturan yang di dalamnya mengatar tentang Kepolisian, dialamatkan agar polisi mampu bersikap dan bertidak profesional, mampu berubah dari peran sebagai alat kekuasaan menjadi aparat penegak hukum yang meindungi masyarakat, dari institusi dan individu yang antagonis menjadi protagonis, dari kecenderungan sebagai crime hunter menuju ke community problem solver. Perubahan-perubahan tersebut menjadi sangat penting untuk diwujudkan, karena wilayah kerja polisis tidak hanya bersiat terioraial, tetapi mencakup cultur dan sosial. charles Reith pernah mengatakan:"The chief element of the power of the police is the approval of the community, and their success depends on their ability to retain it/faktor utama dari kekuatan kepolisian adalah persetujuan atau dukungan masyarakat dan keberhasilanya tergantung pada kemampuan mereka memperoleh dukungan dan persetujuan itu.

Dalam pandangan Barda Nawawi Arief, hukum merupakan tumpuan harapan masyarakat untuk mengatur pergaulan hidup bersama. Hukum merupakan perwujudan atau manifestasi dari nilai kepercayaan. Menurut Barda Nawawi Arief, wajar apabila penegak hukum (Polisi: penulis) diharapkan akan tampil sebagai sosok yang sepatutnya dipercaya dan menegakan wibawa hukum yang pada hakekatnya berarti menegaan nilai kepercayaan di dalam masyarakat. Aspek kepercayaan inilah yang oleh Barda Nawawi Arief dianggap sebagai beban psikologis yang cukup berat bagi polisi sebagai penegak hukum.

3. Prosedur dan kriteria tindak pidana yang diselesaikan dengan perdamain di tingkat penyidikan.

Prosedur pelaksanaan penyelesaian kasus pidana dengan cara islah/perdamaian di Kepolisian Resor (Polres) dan di Kepolisian Sektor (Polsek) pada intinya sama, meskipun menggunakan redaksional yang bebeda, selalu berawal dari pintu unit Pengaduan Masyarakat (Dumas).

Unit Dumas bertugas menerima pengaduan masyarakat, termasuk menerima laporan dan atau pengaduan tentang dugaan telah terjadinya tindak pidana. Pelapor atau pengadu dapat menceritakan kronologis tentang dugaan terjadinya tindak pidana. Atas laporan atau pengaduan tersebut, polisi melakukan penyelidikan. Apabila ternyata hasil penyelidikan, ditemukan ada indikasi tindak pidana, maka akan dilakukan gelar 
perkara untuk menaikan status penyelidikan menjadi penyidikan.

Meskipun di unit Dumas penyelidikan sudah ditingkatkan menjadi penyidikan, pelaku dan korban tetap berkesempatan untuk menentukan sikap model penyelesaian. Apabila pelaku dan korban tetap berkeinginan diselesaikan dengan prosedur formal, korban atau pihak yang dirugikan harus membuat laporan atau pengaduan secara resmi. Setelah ada laporan dan atau pengaduan, baru dilanjutkan dengan penyidikan. Setiap dimulainya penyidikan, penyidik akan membuat Surat Pemberitahuan dimulainya Penyidikan (SPDP) ke Kejaksaan sebagai bentuk koordinasi penanganan perkara.

Untuk memberi kesempatan kepada pelaku dan korban untuk menyelesaikan kasus-kasus tertentu dengan cara islah/ perdamaian pertimbangan kemanfaatan yang lebih besar, baik bagi pelaku, korban dan masyarakat, penyidik akan melakukan penundaan terhadap penyampaian Surat Pemberitahuan dilakukanya Penyidikan (SPDP) kepada Kejaksaan.

Polisi sebagai aparat hukum, ia akan melaksanakan tugas yang bersifat represif yudisial dan juga tugas yang bersifat sosial, seperti mengayomi, melindungi dan melayani masyarakat. Dalam praktik, pelaksanaan kedua tugas ini terkadang dilakukan secara bersaman. Pada situasi yang demikian, maka Polisi akan salalu rentan terhadap penilain masyarakat (Simak Sadjijono: 2008: 196). Polisi sebagai bagian birokrasi pengemban fungsi pengemban pemerintahan dibidang pelayanan umum, ia memiliki kewenangan antara lain diskresi untuk menterjemahkan norma hukum dan kecenderungan sosial tertentu dalam waktu tertentu. Sebagai bagian dari birokrasi peradilan pidana, dalam melakukan penyidikan ia harus tunduk dan patuh pada hukum dan melindungi Hak Asasi Manusia (Simak Sadjijono: 2008: 198).

Pelaku atau pelaku dan korban, berhak untuk memilih bentuk penyelesaian kasus pidana. Pilihan pelaku atau pelaku dan korban untuk memilih prosedur hukum formal dalam menyelesaikan kasus pidana, tidak harus menggunakan ukuran pendapat masyarakat. Setiap kasus memiliki nilai yang berbeda pada setiap orang. Boleh jadi, kasus tertentu oleh masyarakat dianggap tidak bernilai, tetapi oleh korban dianggap sangat bernikai. Subyektifitas penilain terhadap kasus, akan berpengaruh pada pilihan model dalam penyelesaian.
Kriteria kasus pidana yang dapat di selesaikan dengan islah/perdamaian antara lain: (1) tindak pidana yang terjadi adalah masih dalam lingkup keluarga, suami, istri dan anak; (2) pelaku adalah orang yang bekerja membantu dalam pekerjaan tersebut dan menetap dalam rumah tersebut; (3) ancaman pidana tindak pidana tersebut kurang dari 5 tahun; (4) telah ada kesepakatan damai antara pelaku dan korban; (5) kriteria lain yang oleh kebijakan Kapolri dimungkinkan dapat diselesaikan dengan cara Alernative Dispute Resoution (ADR); (6) kedua belah komunikatif dan sepakat secara kekeluargaan; (7) jika kedua belah ada yang meminta ganti rugi, maka dalam surat kesepakatan tersebut, kedua belah pihak menyetujuinya;(8) Surat kesepakatan tersebut dibuat secara tertulis di atas materai.

Secara garis besar, isi surat kesepakatan damai antara pelaku dan korban: (1) Identitas pelaku dan korban; (2) Hari, tanggal dan tahun dibuatnya kesepakatan perdamain; (3) Uraian yang menerangkan Pelaku dan korban sepakat saling memaafkan dan sepakat menyelesaikan kasus pidana sebagaimana yang terjadi dan telah dilaporkan/diadukan ke Polisi dengan perdamaian/islah; (4) Adanya pernyataan perdamaian antara pelalu dan korban yang menyatakan perkara dianggap selesai serta tidak akan ada lagi saling tuntut; (5) Uraian yang menerangkan bahwa pernyataan perdamaian tersebut dibuat dengan tidak ada paksaan dari pihak manapun juga; (5) Nama jelas dan tanda tangan pelaku dan korban; dan (6) Nama jelas dan tanda tangan para saksi; (6) Uraian yang menyatakan,apabila pelaku tidak mengindahkan isi kesepakatan, maka akan diproses sesuai prosdur hukum formal; dan (7) Apabila para saksi adalah berkedudukan sebagai kepala lembaga, maka dilengkapi stempel lembaga yang dimaksud.

Setelah terjadi kesepakatan perdamaian, pelapor/pengadu harus mengajukan permohonan pencabutan laporan/pengaduan. Untuk tindak pidana Kekerasan Dalam Rumah Tangga (KDRT), permohonan pencabutan laporan/pengaduan tersebut, di samping di tandatangani oleh pelapor, juga harus diketahui oleh ketua Rukun Tetangga/RT dan Rukun Warga (RW) di lingkungan tempat tinggal.

4. Dasar pertimbangan perdamaian dalam penegakan hukum pidana pada tingkat penyidikan. 
Pada tahap penyidikan oleh penyidik polri, penguapayaan keadilan tidak lagi menjadi wacana, tetapi telah dipraktikan secara kongkret yang salah satu wujudnya adalah penyelesaian kasus pidana dengan cara islah/perdamaian. Perdamaian/Islah oleh pelaku dan korban dianggap sebagai yang paling adil. Pada pada saat korban sudah mendapatkan pemenuhan atas kerugian akibat tindak pidana dan pelaku sudah mengembalikan hak korban, berarti di dalamnya ada keadilan dan kemanfaatan.

Untuk kasus yang berkaitan dengan harta kekayaan, sebelum dilakukan pemanggilan biasanya pelaku secara informal menemui korban untuk menyelesaikan kasus tersebut dengan cara damai. Pada saat dilakukan pemanggilan oleh polisi, pihak keluarga korban akan mendatangi kantor polisi dan menyampikan bahwa pelaku belum bisa menghadap. Langkah keluarga ini diambil oleh pelaku untuk menghindari pemanggilan yang kedua. Di samping untuk menghindari pemanggilan yang kedua, sebetulnya yang terjadi adalah pelaku belum mendapatkan persetujuan damai dari korban. Setelah mendapatkan persetujuan damai dari korban, korban dan pelaku akan mendatangi kantor polisi dengan membawa surat mencabut laporan dan atau pengaduan yang telah disampaikan pada Polisi.

Penyelesaian perkara dengan cara Islah/ perdamaian yang oleh umum disebut Alternatif Disput Resolution (ADR) disebabkan karena adanya beberapa kelemahan, di antaranya: (a) lambanya penyelesaian perkara; (b) mahalnya biaya perkara; (c) timbulnya masalah baru; (d) peradilan tidak tanggap dan tidak responsif; (e) putusan pengadilan tidak mampu menyelesaiakan masalah secara tuntas; (f) kemampuan dan pengetahuan hakim yang bersifat generalis.

Menurut Satipto Rahardjo, (Adi Sulistiyono: 2006: 18-19), beberapa pertimbangan orang berperkara ke pengadilan, yaitu a. Kepercayaan, yaitu bahwa di tempat itu mereka akan memperoleh keadilan seperti yang di kekehendaki; b. Kepercayaan, bahwa pengadilan merupakan lembaga yang mengekpresikan nilai-nilai kejujuran, mentalitas yang tidak korup dan nilai-nilai utama lainya; c. Bahwa waktu dan biaya yang mereka keluarkan tidak sia-sia; d. Bahwa pengadilan merupakan tempat bagi orang untuk benar-benar memperoleh perlindungan hukum. Harapan-harapan tersebut menurut
Adi Sulistiyono tidak terwujud. Kepercayaan masyarakat tersebut ternyata tidak direspon. Dalam realitasnya pengadilan belum bisa memenuhi harapan masyarakat, karena banyak putusan-putusanya tidak menyelesaikan masalah justru menimbulkan masalah (Adi Sulistiyono: 2006: 19).

Voltaire, Filosofis Perancis pernah mengatakan:"I Was ruined but twice, once when I won a lawsuit and once when I lost/saya mengalami dua kali kekalahan, sekali ketika saya memenangkan gugatan di pengadilan dan sekali lagi ketika saya memang kalah dalam perkara saya. "As a litigant, I should a law suit beyond almost anything else shor of sickness and death"/ sebagai seorang aparat pengadilan, selain penyakit dan kematian, maka saya jauh lebih menakuti suatu gugatan pengadilan dari apa saja. Pengadilan berusaha menemukan kebenaran, akan tetapi menemukan kebenaran dengan memecahan masalah tidaklah sama. Padahal pada saat seseorang mempunyai problem, maka yang dibutuhkan adalah penyelesaian yang adil, cepat,biaya murah padahal dalam praktiknya, semua itu tidak ditemukan di pengadilan. orang cina mengatakan:"The Chinese say: A lawsuit breeds ten years of hated/suatu gugatan ke pengadilan memelihara sepuluh tahun kebencian (Achmad Ali: 2004: 19).

Menurut Anthon, membengkaknya perkara dengan jumlah penyelesaian tersendat, buruknya pelayanan, terbatasnya alternatif penyelesain sengketa, distorsi komunikasi sampai kepada 'jorok' dan 'kumuhnya' pengadilan merupakan refleksi ketidakmampuan pengadilan untuk memberdayakan diri. Rasa skeptis yang meluas mengenai mutu pengadilan yang dihasilkan pengadilan merupakan akumulasi akhir. Keadilan menjadi (lebih) berharga mahal dan mereka ingin "membelinya" (ke pengadilan), pasti hanyalah mereka yang mampu menyediakan uang sebagai imbalanya (Anthon Freddy Susanto: 2005: 139).

Penyelesaian tindak pidana dengan cara islah/perdamaian sebagai bagian dari Alternative Dispute Resolution (ADR), merupakan langkah yang tepat dan sangat diperlukan untuk mencapai penyelesaian terbaik. Manfaat bagi Polisi adalah perkara tersebut cepat selesai/Crime Clier (cc). Manfaat bagi pelaku dan korban adalah memperbaiki hubungan sosial dan kekeluargaan yang lebih harmonis. 
Manfaat penyelesaian kasus pidana dengan cara islah/perdamaian, bagi Polisi tingakat penyelesaian perakara meningkat, sebagai akibat pengaduan atau laporan dicabut kembali. Bagi pelaku manfaatnya adalah ia menyadari perbuatanya melanggar hukum. Bagi korban manfaatnya adalah kerugian yang diderita oleh korban bisa kembali, tidak ada perasaan saling dendam.

Secara umum, manfaat penyelesaian kasus pidana dengan cara islah/perdamaian: (a) prosesnya lebih cepat; (b) biaya lebih murah; (c) sifatnya informal karena segala sesuatunya ditentukan oleh pihak yang bersangkutan/bersemgketa; (d) kerahasiaan terjamin; (e) adanya kebebasan memilih pihak ketiga; (f) menjaga hubungan baik; (g) mudah mengadakan perbaikan; (h) bersifat final sesuai dengan kesepakatan; (i) adanya pertemuan/tatap muka pihak yang bersengketa; dan (j) tata cara penyelesaian sengketa diatur sendiri oleh para pihak yang bersengketa.

\section{Relevansi dan format Islah}

Baik berdasarkan literatur maupun dalam praktik peradilan (penyidikan), penyelesaian tindak pidana dengan perdamaian tidak disebut sebagai Islah. Istilah yang sering mengemuka, antara lain adalah mediasi penal (penal mediation), ADR (Alternative Dispute Resolution) dan Restorative Justice.

Negara yang telah menetapkan model penyelesaian pidana di luar jalur hukum pidana/mediasi penal (penal mediation), atau dikenal juga dengan istilah ADR (Alterantive Dispute Resoution) dan Restorative Justice, antara lain Austria, Belgia, Jerman, Perancis, Polandia, Italia, dan Australia (.Barda Nawawi Arif: 2008: 8-9).

Dalam perspektif internasional, Restorative Justice juga telah menjadi agenda Perserikatan Bangsa-Bangsa (PBB). Terdapat beberapa konferensi konggres Perserikatan Bangsa-Bangsa (PBB) yang menunjukan arah pemberlakuan Restorative Justice. Dalam konggres PBB ke 9 Tahun 1995 tentang manajemen peradilan pidana (dokumen A/coNF 169/6) menghendaki agar dalam penyelesaian kasus pidana mengikutsertakan ADR (Alternative Dispute Resolution) berupa mediasi, konsiliasi, restitusi dan kompensasi. Dalam konferensi Internasional Pembaharuan Hukum Pidana/ International Reform Conferensi Tahun 1999, PBB juga menyerukan kepada negara agar memparkaya sistem peradilan formal dengan peradilan informal. Dalam konggres PBB ke 10 tahun 2000 (dokumen A/coNF.187/4/4/ Rev.3) mengamatkan kepada negara untuk melindungi korban tindak pidana dengan cara mengakomodasi kepentingan korban dalam mekanisme peradilan, melalui mediasi dan peradilan restoratif. (Lilik Mulyadi: 2013: 8-9).

Barda Nawawi Arief yang mengutip hasil konggres PBB tentang The Prevention of Crime and the Treatment of Offender, menegasakan bahwa dalam pencegahan/ penanggulangan kejahatan seyogyanya lebih banyak dilihat dari konteks kebijakan pembangunan/sosial global. Strategi kebijakan penanggulangan/pencegahan kejahatan menurut menurut Barda Nawawi Arief adalah: a. Pencegahan kejahatan dimaknai sebagai upaya meniadakan faktor penyebab/kondisi yang menimbulkan terjadinya kejahatan. b. Pencegahan kejahatan seyogyanya ditempuh dengan kebijakan integral/ sistemik dan terpadu, yaitu keterpaduan antara kebijakan penanggulangan kejahatan dengan seluruh kebijakan pembangunan sistem PoLEKSoSBUD, keterpaduan antara treatment of offenders (dengan pidana/tindakan) dan treatment of society, keterpadua antara pengobatan simptamotik dengan pengobatan kausatif, keterpaduan antara treatment of offenders dan treatment of victim, keterpaduan antara individual/personal responsibility dengan structure/fungcional responsibility, keterpaduan sarana penal dan saraan nonpenal, keterpaduan formal dan informal, keterpaduan antara legal system dan extra legal system, serta keterpaduan antara policy oriented approach dan value oriented approach. (Barda Nawawi Arief: 2008: 81-85)

Pada dasarnya Restoratif Jutice adalah model penyelesaian kasus pidana di luar pengadilan yang dalam pelaksanaannya melibatkan pelaku, korban, lembaga sosial, penegakan hukum dan masyarakat. Landasan pemikiran penyelesaian kasus pidana dengan Restorative Justice adalah Pertama, kejahatan merupakan masalah individu dan akibat dari kejahatan bukan hanya akan dirasakan oleh pelaku, akan tetapi juga dapat dirasakan oleh masyarakat meskipun secara tidak langsung, sehingga dalam penyelesainya menjadi masalah bersama. Kedua, penyelesaian kasus pidana dengan Restorative Justice merupakan bentuk eksaminasi atas jalanya sistem peradilan 
pidana yang sulit ditembus oleh masyarakat. Kesulitan tersebut bukan hanya dalam tahap prosedur, akan tetapi putusan pengadilanpun sulit dikoreksi, kecuali dengan cara upaya hukum. Ketiga, penyelesaian kasus pidana dengan Restorative Justice sebetulnya merupakan sebuah komitmen semua pihak untuk menyatakan bahwa kejahatan bukan hanya merupalan masalah Undang-Undang, akan tetapi merupakan masalah manusia, sehingga dalam penyelesainyapun harus menggunakan pendekatan kemausiaan.

Islah hanya dikenal dalam hukum pidana Islam. Dalam praktik penyidikan dan dalam litertur tidak mengenal kata islah. Kata yang sering digunakan adalah mediasi penal (penal mediation), ADR (Alternative Dispute Resolution) dan Restorative Justice. Pertanyanya adalah bagaimanakah relevansi substansi Islah menurut hukum Islam dengan istilah-istliah tersebut.

Berbicara tentang ekistensi Islah sebagai alasan penghapus pidana, alasan pembenaranya ditercantum dalam Al-Qur'an:

'’Barangsiapa yang mengerjakan kejahatan, maka tidak dibalas melainkan dengan balasan yang seimbang, maka barangsiapa yang memaafkan dan mengadakan perdamaian, maka pahalanya atas Allah. Sesungguhnya Dia tidak menyukai orang-orang yang aniaya (A-Qur'an, AsySyuuraa: 40).

Mengacu pada ayat di atas, dapat dipahami: 1. orang yang melakukan kejahatan, maka ia akan mendapatkan balasan sesuai dengan kejahatanya. 2 . orang yang menjadi korban kejahatan, dilegalkan untuk memberikan balasan yang sama kepada pelaku kejahatan. 3. Dalam proses pembalasan atas kejahatan yang terjadi, dimungkinkan untuk dilalukukan perdamaian/Islah antara pelaku kejahatan dan korban kejahatan. 4. Korban kejahatan yang memaafkan pelaku kejahatan yang kemudian tidak melakukan perbuatan yang sama sebagai bentuk pembalasan, maka balasan atas kebaikanya menjadi tanggungan Allah SWT.

Apabila menelaah makna pemahaman Al-Qur'an, A-Qur'an, Asy-Syuuraa: 40), maka dapat diketahui bahwa Islam menawarkan dua pilihan dalam penyelesaian kasus pidana, yaitu melakukan pembalasan dan memaafkan. Atau dengan kata lain, Islam membolehkan penjatuhan sanksi pidana bagi pelaku tindak pidana dan membolehkan tidak menjatuhkan pidana/memaafkan. Menjatuhkan pidana dan memaafkan, kedua-keduanya merupakan pilihan yang diperbolehkan, akan tetapi memaafkan dan tidak menjatuhkan sanksi bagi pelaku tidak pidana atas ijin/kerelaan/keikhlasan dari pelaku, menduduki derajat yang lebih tinggi disisi Allah SWT.

Islah merupakan kewajiban bagi setiap manusia, baik sebagai individu maupun kelompok masyarakat. Ruang Islah sangat luas, dan yang tidak boleh hanyalah islah yang di dalamnya mengkhalalkan yang haram dan mengharamkan yang halal. Dalam Islam, penggunaan Islah sebagai pilihan dalam penyelesaian kasus pidana sudah dikenal jauh sebelum dunia memperkenalkan teori Restorative Justice. Islam teah penempatkan penggunaan Islah sebagai model penyelesaian kasus pidana, sebagai upaya yang pertama bersamaan dengan penerapan sanksi pidana. Pemberlakuan Islah sebagai pilihan penyelesaian kasus pidana

Tindak pidana yang diselesaikan dengan cara Islah/perdamaian pada tingkat penyidikan dikelompokan menjadi: (1) Kejahatan yang berhubungan dengan harta kekayaan; (2) Kejahatan terhadap nyawa atau badan secara jasmani, yaitu kejahatan yang akibatnya korban mendapat rasa tidak secara fisik; (3) Kejahatan yang berhubungan dengan kesusilaan; (4) Kejahatan yang berhubungan dengan kehormatan/harga diri. (5) Kejahatan yang berhubungan dengan ketentuan admnistrasi perkawinan; dan (6) Kejahatan yang berhubungan pelanggaran hak anak.

Untuk kejahatan yang berhubungan dengan harta kekayaan dan kejahatan yang berhubungan dengan kesusilaan, dalam hukum pidana Islam termasuk dalam kelompok Jarimah hudud. Untuk kejahatan Kejahatan terhadap nyawa atau badan secara jasmani, yaitu kejahatan yang akibatnya korban mendapat rasa tidak secara fisik, dalam hukum pidana Islam termasuk kelompok Jarimah kisas. Untuk kejahatan yang berhubungan dengan kehormatan/harga diri, kejahatan yang berhubungan dengan ketentuan admnistrasi perkawinan; dan kejahatan yang berhubungan pelanggaran hak anak, termasuk dalam jarimah takzir.

Pembahasana tentang relevansi dan format Islah pada tingkat penyidikan, mencakup kajian substansi, struktur dan kultur. 


\section{1). Substansi}

Menurut Friedman, berbicara tentang substansi hukum di dalamnya bukan hanya berbicara tentang undang-undang, akan tetapi mencakup pula hukum yang hidup dalam komunitas tertentu (Ahmad Ali: 2001: 7-9). Sementara ini, apabila berbicara penyidikan, hanya memfokuskan iventarisasi hukum formal (hukum acara) dan pelaksanaannya. Kebiasaan-kebiasaan yang ada dalam praktik penyelesaian kasus pidana di tingkat penyidikan, seperti perdamaian/ islah antara korban dan pelaku tidak mendapat perhatian dan belum dianggap sebagai bagian Sistem Peradilan Pidana/ SPP/Criminal Justice System.

Dengan mengacu saat munculnya kecenderungan-kecenderungan internasional tentang restorative justice dan alternative dispute resolution baik yang kemudian ditegaskan dalam konggres Perserikatan BangsaBangsa (PBB) maupun yang tidak, yang kemudian di hubungkan dengan eksistensi Al-Qur'an sebagai sumber dari segala sumber hukum yang di dalamnya melegalkan islah sebagai model penyelesaian kasus pidana, maka dapat diketahui bahwa hukum Islah tetap relevan dengan kondisi saat ini.

Hukum Positip Indonesia, secara normatif belum mengakomodasi model restorative Justice dan alternative dispute resolution dalam penyelesaian kasus pidana, demikian juga dalam penyidikan, demikian juga dalam konsep Kitab Undang-Undang Hukum Acara Pidana (KUHAP) dan konsep Kitab UndangUndang Hukum Pidana (KUHP).

Konsep Kitab Undang-Undang Hukum Acara Pidana (Konsep KUHAP), memungkinkan seorang Jaksa Penuntut Umum untuk menghentikan penuntutan kepada pelaku dengan pertimbangan: a. tindak pidana tersebut termasuk tindak pidana ringan; $b$. tindak pidana tersebut diancam maksimal 1 (satu) tahun; c. tindak pidana tersebut diancam hanya dengan ancaman pidana denda; d. umur tersangka di atas 70 (Tujuh Puluh) tahun; dan atau e. kerugian sudah diganti (Simak Pasal 13 ayat (2) Konsep KUHAP Nasional. Kewenangan Jaksa Penuntut Umum disebut sebagai hak oportunitas, yaitu kewenangan Jaksa
Penuntut Umum untuk tidak melakukan penuntutan.

Konsep Kitab Undang-Undang Hukum Pidana (Konsep KUHP Nasional), tidak mengakomodasi perdamaian/ islah antara pelaku dan korban sebagai alasan penghapus pidana, tetapi hanya menjadi kondisi/keadaan pelaku yang wajib dipertimbangkan oleh hakim dalam menjatuhkan putusan. Konsep KUHP Nasional hanya menjelaskan tujuan pemidanaan, pedoman pemidanaan dan hal-hal yang harus dipertimbangkan oleh hakim dalam menjatuhkan putusan.

Menurut pasal 54 ayat (1) Konsep KUHP Nasional, pemidanaan bertujuan: 1. Mencegah dilakukanya tindak pidana dengan menegakan hukum demi pengayoman; 2. Memasyarakatkan terpidana dengan mengadakan pembinan sehingga menjadi orang yang baik dan berguna; 3 . Menyelesaikan konflik yang ditimbulkan oleh tindak pidana, memulihkan keseimbangan, dan mendatangkan rasa damai dalam masyarakat; dan 4. Membebaskan rasa bersalah pada terpidana. Pemidanaan tidak dimaksudkan untuk menderitakan dan merendahkan martabat manusia (Pasal 54 ayat (2) Konsep KUHP Nasional).

Pasal pasal 55 ayat (1) Konsep KUHP Nasional menegaskan, dalam pemidanaan hakim wajib mempertimbangkan: 1. Kesalahan pembuat tindak pidana; 2. Motif dan tujuan melakukan tindak pidana; 3 . Sikap batin pembuat tindak pidana; 4 . Tindak pidana yang dilakukan apakah direncanakan atau tidak direcanakan; 5. cara melakukan tindak pidana; 6 . Sikap dan tindakan pembuat sesudah melakukan tindak pidana; 7 . Riwayat hidup, keadaan sosial dan ekonomi pembuat tindak pidana; 8. Pengaruh pidana terhadap masa depan pembuat tindak pidana; 9. Pengaruh tindak pidana terhadap korban atau keluarga korban; 10. Pemaafan dari korban dan/atau keluarganya; dan atau 11. Pandangan masyarakat terhadap tindak pidana yang dilakukan.

Ringanya perbuatan, keadaan pribadi pembuat, atau keadaan pada waktu dilakukan perbuatan atau terjadi kemudian,dapat dijadikan dasar 
pertimbangan untuk tidak menjatuhkan pidana atau mengenakan tindakan dengan mempertimbangkan segi keadilan dan kemanusiaan (Pasal 55 ayat (2) Konsep KUHP Nasional).

Dengan tetap mempertimbangkan Pasal 54 dan Pasal 55, pidana penjara sejauh mungkin tidak dijatuhkan, jika dijumpai keadaan-keadaan: 1. Terdakwa berusia dibawah 18 (delapan belas) tahun atau diatas 70 (tujuh puluh) tahun; 2. Terdakwa baru pertama kali melakukan tindak pidana; 1. Kerugian dan penderitaan korban tidak terlalu besar; 2. Terdakwa telah membayar ganti kerugian kepada korban; 3. Terdakwa tidak mengetahui bahwa tindak pidana yang dilakukan akan menimbulkan kerugian yang besar; 4. Tindak pidana terjadi karena hasutan yang sangat kuat dari orang lain; 5 . Korban tindak pidana mendorong terjadinya tindak pidana tersebut; 6 . Tindak pidana tersebut merupakan akibat dari suatu keadaan yang tidak mungkin terulang lagi; 7 . Kepribadian dan perilaku terdakwa meyakinkan bahwa ia tidak akan melakukan tindak pidana yang lain; 8. Pidana penjara akan menimbulkan penderitaan yang besar bagi terdakwa atau keluarganya; 9. . Pembinaan yang bersifat non-institusional diperkiraakan akan cukup berhasil untuk diri terdakwa; 10. Penjatuhan pidana yang lebih ringan tidak akan mengurangi sifat beratnya tindak pidana yang dilakukan terdakwa; dan 11. Tindak pidana terjadi di kalangan keluarga; atau n. Terjadi karena kealpaan (Pasal 71 Konsep KUHP Nasional).

Mengacu pada beberapa pasal dalam konsep Kitab Undang-Undang Hukum Acara Pidana (Konsep KUHAP Nasional ) dan Konsep Kitab UndangUndang Hukum Pidana (Konsep KUHP Nasinal), dapat diketahui: Pertama, permaafan antara korban dan pelaku dan atau keluarga korban dan keluarga pelaku serta pemberian ganti kerugian oleh pelaku kepada korban tidak secara otomatis menjadi dasar penghalus pidana, melainkan hanya menjadi pertimbangan bagi hakim agar sejauh mungkin tidak menjatuhkan pidana bagi pelaku. Kedua, ganti rugi oleh pelaku kepada korban menjadi dasar bagi Jaksa Penuntut Umum (JPU) untuk tidak melakukan penuntutan kepada terdakwa.

Menurut hukum Islam, antara korban dan pelaku dan atau keluarga pelaku dan korban, dimungkinkan untuk melakukan perdamaian/islah, selama kasus tersebut belum sampai di meja hakim. Mengacu pada teori ini, maka pelaksanaan perdamaian/iskah ditingkat penyidikan dan keadaan atau kondisi yang demikian disebut oleh Friedman sebagai hukum yang hidup (living law), yang keberadannya merupakan bagian dari substansi hukum. Dengan mengacu pada pendapat Friedman, maka dalam konteks perdamaian/islah dalam penegakan hukum pidana pada tingkat penyidikan, untuk substansi ini, mencakup undang-undang materiil dan undang-undang formal.

Jenis tindak pidana yang dapat dilakukan perdamaian yang relevan dengan islah menurut hukum Islam, mencakup (1) Kejahatan yang berhubungan dengan harta kekayaan dan korban kejahatan tersebut korbanya bersifat personal bukan harta milik negara dan antara pelaku dan korban berkehendak untuk berdamai/ islah ; (2) Kejahatan terhadap badan jasmani yang tidak menimbulkan kematian, yaitu penganiayaan/kekerasan terhadap badan/fisik yang akibatnya korban mendapat rasa tidak secara fisik dan antara pelaku dan korban berkehendak untuk berdamai/ islah; (3) Kejahatan yang berhubungan dengan kesusilaan yang bukan perzinahan; (4) Kejahatan yang berhubungan dengan kehormatan/ harga diri dan antara pelaku dan korban berkehendak untuk berdamai/islah ; (5) Kejahatan-kejahatan yang berhubungan dengan ketentuan administrasi dan antara pelaku dan korban berkehendak untuk berdamai/islah ; (6) Penyelesaian kasus pidana dengan perdamaian, tidak berlaku bagi residivis.

Untuk hukum formal/acara, penyelesaian kasus pidana dengan perdamaian di lakukan pada tahap penyidikan. Pertimbanganya, setelah dilakukan penyidikan dapat diketahui salah atau tidaknya seseorang (di satatuskan sebagai tersangka) dan juga telah ditemukan barang bukti. Pertimbangan lainya, untuk 
meminimalisasikan terjadinya kerugian pada tahap selanjunya, seperti tahap penunutan dan pemeriksaan pengadilan.

Prosedur yang mesti ditempuh: (1) Polisi/penyidik melakukan pemanggilan pelaku berdasarkan laporan atau pengaduan; (2) Polisi/pemyidik melakukan pemanggilan korban, pelapor atau pengadu; (3) Dilakukan penyidikan terhadap pelaku; (4) Polisi/ penyidik mempertemukan pelaku dan korban untuk kepentingan penentuan model penyelesaian kasus pidana; (5) Apabila pelaku dan korban menghendaki penyelesaian dengan perdamaian, maka harus dibuktikan dengan surat pernyataan damai antara pelaku dan korban, dengan ketentuan apabila masing-masing tidak melaksanakan pernyataan yang dibuat, maka prosedur formal tetap diberlakukan; (6) Surat pernyataan perdamaian tersebut, di tanda tangani oleh pelaku, korban, saksi dan diketahui oleh polisi/penyidik;

- (7) Apabila pelaku dan korban tetap menghendaki prosedur hukum pidana, maka Polisi/penyidik tetap melaimpahkan perkara ke Jaksa Penuntut Umum; (8) Apabila telah disepakati penyelesaian kasus pidana dengan perdamaian, maka polisi/penyidik menetapkan Surat Perintah Penghentian Penyidikan/ SP3 (9) Keberatan terhadap SP3 dikemudian hari, hanya dimungkinkan atas permohonan yang bersangkutan.

\section{2). Struktur.}

Menurut Friedman, struktur adalah kerangka atau rangkanya, bagian yang memberi semacam bentuk batasan terhadap keseluruhan. Achmad Ali menerjemahkan struktur dalam konteks sistem hukum di Indonesia adalah penegak hukum, yang meliputi Kepolisian, Kejaksaan, Kehakiman dengan segala lingkup dan tingkatanya. (Ahmad Ali: 2001: 7-9). Soerjono Soekanto, tidak menggunakan istilah struktur hukum, tetapi penegak hukum sebagai komponen penegakan hukum, yaitu pihak yang membuat dan menerapkan hukum (Soerjono Soekanto: 2011: 8). Barda Nawawi Arief, menggunakan istilah stuktur hukum dengan penegak hukum, yang dalam Sistem Peradilan Pidana diartikan sebagai "sistem kekuasaan menegakan hukum pidana" atau "sistem kekuasaan kehakiman di bidang hukum pidana" diwujudkan/ diimplementasikan dalam 4 (empat) sistem,yaitu a. Kekuasaan "penyidikan" (oleh badan/lembaga penyidik); b. Kekuasaan "penuntutan" (oleh badan/ lembaga penuntut); c. Kekuasaan "mengadili" dan "menjatuhkan putusan/ pidana" (oleh badan pengadilan); dan d. Kekuasaan "pelaksnaan putusan/ pidana" (oleh badan/aparat pelaksana/ eksekusi). Keempat tahap/susbsistem itu merupakan satu kesatuan sistem penegakan hukum pidana yang integral atau sering disebut "Sistem Peradilan Pidana (SPP) terpadu (integrated criminal justice system). Dengan kata lain menurut Barda Nawawi, kekuasaan kehakiman di bidang hukum pidana, bukan hanya diwujudkan dalam "kekuasaan mengadili", melainkan juga diwujudkan/diimplementasikan dalam sistem dalam 4 (empat) tahap kekuasaan (Barda Nawawi Arief: 1998: 39-41).

Menurut Barda Nawawi Arief, tugas menegakan hukum yang berkeadilan dan melindungi harkat dan martabat manusia, juga menjadi tugas Polri sebagai penyidik. Salah satu sasaran, tugas Polri dalam bidang penegakan hukum adalah memberikan perlindungan keamanan dari kejahatan dengan sasaran "perlindungan masyarakat". Lebih lanjut dijelaskan, bahwa "perlindungan masyarakat" sebagaimana ditegaskan pada Seminar Kriminologi ke-3, tahun 1976, hukum pidana hendaknya dipertahankan sebagai salah satu sarana untuk "social defence" dan arti melindungi masyarakat terhadap kejahatan dengan memperbaiki atau memulihkan kembali (rehabilitasi) si pembuat tanpa mengurangi keseimbangan kepentingan perorangan (pembuat) dan masyarakat (Barda Nawawi Arief: 1998: 8). Penanggulangan kejahatan dengan menggunakan sarana "penal" mempunyai kelemahan, kekurangan dan keterbatasan. Sepatutnya, dimbangi dengan upaya non penal yang harus digali dan dimanfaatkan dan dikembangkan. Pengembangan upaya non-penal lewat program kegiatan polisi yang berorientasi pada pelayanan masyarakat, komitmen yang demikian menurut Barda Nawawi Arief merupakan hal yang wajar, bahkan 
merupakan keharusan (Barda Nawawi Arief: 1998: 8).

Apabila hukum yang hidup (living law) merupakan bagian dari substansi dalam sistem hukum dan urgensi tugas polisi yang lebih mengarah pada tugas pelayanan, maka peran polisi sebagai inisiator dan mediator dalam penyelesaian kasus pidana dengan perdamaian/isah, makan pelayanan yang demikian dimaknai sebagai bagian penegakan hukum.

Pada prinispnya peradilan dilakukan dengan sederhana, cepat dan biaya ringan. Asas umum penyelenggaraan peradilan ini mengamanatkan kepada para penegak hukum untuk mencari terobosan-terobosan hukum, sehingga dalam pelaksanaanya dapat berjalan sebagaimana mestinya dan bukan sebagaimana adanya.

Menurut Soerjono Soekanto, faktor yang dapat berpengaruh pada penegakan hukum diantaranya adalah faktor masyarakat. Untuk hal-hal tertentu untuk kasus-kasus yang pelaku dan korbanya adalah masyarakat biasa, antara pelaku dan korban menghendaki proses hukum yang cepat, sederhana dan biaya ringan. Harapan yang demikian, tentunya tidak akan terbukti sepanjang aparat penegak hukum hanya melihat hukum sebagaiamana yang ada dalam Undang-Undang, sementara masyarakat menganggap bahwa hukum adalah sesuatu yang menguntungkan bagi mereka.

Penyelesaian kasus pidana dengan cara perdamaian/islah merupakan manivestasi hukum dalam masyarakat dan hal yang demikian juga menunjukan bahwa hukum bagi mereka adalah kesepakatan antara mereka dalam menyelesaikan kasus hukum. Kesepakatan antara pelaku dan korban, di dalamanya perlu adanya keterlibatan penegak hukum (polisi), sehingga keberlakuanya dapat berjalan dengan baik.

Untuk melaksanakan perdamaian dalam penyelesaian kasus pidana, di samping mendasarkan pada budaya hukum masyarakat juga mendasarkan pada budaya hukum penegakan hukum (polisi). Adanya surat kesepakatan perdamaian/islah antara pelaku dan koran dan atau keluarga pelaku dan korban, menunjukan bahwa budaya hukum masyarakat dalam hal-hal tertentu demikian adanya.

Dengan adanya penyelesaian kasus pidana dengan cara perdamaian/islah pada tingkat penyidikan, setidaktidaknya telah menunjukan bahwa tugas polisi bukan hanya membuat Berita Acara Pemeriksaan (BAP) yang selanjutnya dilimpahkan ke pengadilan, meliankan ia telah diperankan sebagai penegak hukum. Sementara ini, berdasarkan undang-undang, polisi dalam kedudukanya sebagai penyidik hanya berperan sebagai tenaga administrasi hukum dan bukan sebagai penegak hukum.

Penyidik berperan untuk memfasilitasi pelaksanaan perdamaian kasus pidana di tingkat penyidikan. Untuk memupuk tanggung jawab pada pelaku, maka untuk sebagian pembiayaan dibebankan kepada pelaku dan setiap penerimaan dalam proses ini harus diberikan kuintansi penerimaan.

3). Kultur.

Penyelesaian kasus pidana dengan cara perdamaian/islah pada tingkat penyidikan, merupakan koreksi atas pemberlakuan sistem hukum yang hanya dimiliki oleh para pembentuk UndangUndang. Hukum bukan hanya miliki dan produk pembentuk Undang-Undang. Hukum juga dimiliki oleh masyarakat dan tercermin dalam perilaku mereka dalam menyelesaian kasus hukum sebagai maniverstasi budaya hukum yang mereka miliki.

Kebuadayaan dalam sistem hukum menurut Soerjono Soekanto mencakup nilai-nilai yang mendasari berlakunya hukum, nilai-nilai sebagai konsep abstrak tentang sesuatu yang baik sehingga perlu diikuti dan sesuatu yang yang tidak baik, sehingga perlu dihindari. Lebih lanjut menurut Soerjono Soekanto, nilai-nilai tersebut merupakan pasangan nilai yang harus diselesaikan, seperti ketertiban dan ketenteraman, kebendaan dengan kerohanian atau keahlakan, konservatisme dan kebaruan/inovatif (Soerjomo Soekanto: 2011: 59-60). Menurut otje Salman, saat ini berbicara tentang hukum tidak lagi berkutat pada 
persoalan legalitas formal, penafsiran undang-undang yang semestinya diberlakukan, melainkan akan beralih dan bergerak ke arah penggunaan hukum sebagai sarana membentuk tata kehidupan yang baru atau mencari hukum yang paling sesuai dengan kondisi saat itu (otje Salman: 2001: ).

Achmad Ali memaknai makna legal kultur sebagaimana dimaksud oleh Friedman, sebagai sikap manusia terhadap hukum dan sistem hukum kepercayaan, nilai, pikiran serta harapanya. Atau dengan kata lain adalah suasana pikiran sosial dan kekuatan sosial yang menentukan bagaimana hukum digunakan, dihindari atau digunakan (Ahmad Ali: 2001: 7-9).

Untuk pelaksanaan perdamaian dalam kasus pidana pada tingkat penyidikan, kata kuncinya terletak pada Polisi, meskipun peran pelaku dan korban tidak harus diabaikan. Sikap korban kejahatan selalu tertumpu pada dua hal, yaitu ingin membalas pelaku sehingga pelaku harus diproses melalui prosedur hukum pidana dan tidak ingin menuntut pelaku, dengan catatan kerugian baik harta maupun fisik dapat dipulihkan.

Apabila korban menginginkan damai dengan pelaku dan pelaku siap memenuhi permintaan pelaku, maka keduanya harus difasilitasi oleh polisi/penyidik . Untuk memfasilitasi penyelesaian kasus pidana dengan perdamaian, maka diperlukan polisi yang berkultur menyelesaikan masalah dan bukan yang berkultur semengat menghukum orang yang bersalah.

\section{Simpulan}

Secara normatif, penyelesaian perkara pidana dengan perdamaian pada tingkat penyidikan, tidak dikenal. Model penyelesaian yang demikian, didasarkan pada kesepakatan antara pelaku dan koran. Perkara pidana tersebut bersifat personal yang nilai kerugianya, oleh pelaku dan korban dinilai relatif kecil. Korban dan pelaku beranggapan, apabila perkara tersebut telah diselesaikan dengan perdamaian, maka penyelesaian dengan menggunakan hukum formal tidak diperlukan.

Pelaku dan korban dan/atau keluarganya berperan dalam membuat kesepakatan damai yang dalam pelaksanaanya difasilitasi oleh penyidik. Apabila pelaku atau korban melanggar kesepakatan, maka prosedur hukum formal tetap akan dijalankan. Keberadaan penyelesaian perkara pidana dengan perdamaian, merupakan koreksi atas lembanya penyelesaian dengan menggunakan hukum formal, mahalnya biaya perkara, penggunaan prosedur formal yang terkadang menyisakan masalah, tidak responsifnya peradilan.

Islam menempatkan perdamaian/islah sebagai alternatif dalam penyelesaian perkara pidana, sepanjang perkara tersebut belum sampai ke tangan hakim. Dalam literatur dan dalam praktik, model penyelesaian perkara dengan perdamaian disebut Alternative Disput Resolution (ADR) yang mendasarkan pada teori Restorative Justice.

Sebelum dunia mengenalkan istilah Alternative Disput Resolution dan Restorative Justice atau yang sejenis dengan itu, baik yang ditegaskan dalam Konggres Perserikatan BangsaBangsa maupun yang tidak, Al-Qur'an lebih dulu mengatur tentang perdamaian/islah sebagai model penyeledaian perkara pidana. Pada prinsipnya, peradilan dalam menyelesaikan perkara, harus mendasarkan pada asas cepat, sederhana, dan biaya ringan. Asas ini dapat diwujudkan dengan cara menyelesaian perkara pidana dengan perdamaian pada tingkat penyidikan.

\section{E. Saran}

Di masa datang, untuk perkara pidana: (1) yang terjadi antara personal atau individual; (2) akibat tindak pidana tersebut bersifat personal atau individual; (3) Nilai kerugian menurut pelaku dan korban relatif kecil; (4) antara pelaku dan korban sudah bersepakat untuk berdamai/islah dengan segala konsekuensinya; dan (5) bukan pengulangan/residivis, seyogyanya diakomodasi dalam Undang-Undang sebagai alasan pengapus pidana dan penerapanya pada tingkat penyidikan 


\section{Daftar Pustaka.}

Muhammad Taufik, 2013, Model Penyelesaian Perkara Yang Berkedailan Substansial, Rigkasan Disertasi, Program Doktor IImu Hukum, Fakultas Hukum Universitas Sebelas Maret.

Satjipto Rahardjo. 2010. Penegakan Hukum Progesif. Jakarta. Agustus. Kompas.

2010. Sosiologi Hukum Esei-Esai Terpilih.ctk. Pertama. Yogyakarta. Maret. Genta Publishing.

2011. Penegakan Hukum suatu Tinjauan Sosiologis. ctk. Kedua. Yogyakarta. Genta

Publishing.

Nurhasan Ismail. 2012. IImu Hukum Dalam Perspektif Sosiologis (Obyek berbincangan yang terpinggirkan). Konggres IImu Hukum Refleksi dan Rekontruksi IImu Hukum Indonesia, Bagian Hukum dan Masyarakat, Fakultas Hukum, Unviersitas Diponegoro, Semarang, 19-20 oktober 2012.

Suteki, Menjadi Penegak Hukum Progesif Demi Keadilan Substantif, Makalah disampaikan pada Konsersium Hukum Progesif, "Dekontruksi Gerakan dan Pemikiran Hukum Progresif", Satjipto Rahardjo Institue, Hotel Patra Jasa, Semarang, 29-30 November 2013,

I.S. Susanto. Kejahatah Korporasi. Semarang. Badan Penerbit Universitas Diponegoro.

2011. Kriminologi. ctk.Pertama. Yogyakarta. Maret. Genta Publishing

Adi Sulistiyono.2008. Negara Hukum: Kekuasaan, Konsep dan Paradigma Moral. (Ishayanto, Kundharu Saddhono dan Kunardi Hardjoprawiro: editor). ctk. Kedua. Surakarta. Lembaga Pengembangan Pendidikan (LPP) UNS dan UPT Penerbitan dan percetakan UNS (UNS Press).

2006. Mengembangkan Paradigma Non-Litigasi di Indonesia (Ishryanto: editor). ctk. Kesatu. Surakarta. September. UPT Penerbitan dan percetakan UNS (UNS Press).

2006. Krisis Lembaga Pradilan di Indonesia. ( Ishayanto, Kundharu Saddhono dan Sri Jumini: editor). ctk. Kesatu. Surakarta. Lembaga Pengembangan Pendidikan (LPP) UNS dan UPT Penerbitan dan percetakan UNS (UNS Press).

Achmad Ali. 2004. Sosiologi Hukum Kajian Empiris Terhadap Pengadilan. ctk. Pertama. Jakarta. September. Badan Penebit Iblam.

Anthon Freddy Susanto. 2005. Semiotika Hukum Dari Dekontruksi Teks Menuju Progresivitas Magna. ctk. Pertama. Bandung Juli. Refika Aditama.

Naorouzzaman Shiddiqi. 1993. Fiqh Indonesia, Penggagas dan Gagasanya. Yogyakarta. Pustaka Pelajar.

Barda Nawawi Arief, 2008. Mediasi Penal: Penyelesaian Perkara Pidana di Luar Pengadilan. Semarang. Program Magister IImu Hukum Universitas Diponegoro.

Barda Nawawi Arief. 1998. Beberapa Aspek Kebijakan Penegakan dan Pengembangan Hukum Pidana. Bansung. PT. citra Aditya Bakti.

Lilik Mulyadi. 2012. Mediasi Penal Dalam Sistem Peradilan Pidana: Pengkajian Asas, Norma, Teori dan Praktik, Yustisi, Jurnal Hukum, Edisi 85, Januari-April 2013, Tahun XXII, Fakultas Hukum, Universitas Sebelas Maret, Surakarta.

Achmad Ali, 2001. Keterpurukan Hukum di Indonesia (MS. Khadafi: editor. ctk. Pertama. Jakarta. Januari Ghalia Indonesia.

Soerdjono Soekanto. 2011. Faktor-Faktor yang Mempengaruhi Penegakan Hukum. ctk. Kesepuluh. Jakarta. PT. RajaGrafindo Persada.

otje Salman. 2001. Beberapa Aspek Sosiologi Hukum. ctk. Kesatu. Bandung. Alumni.

. 2009. Filafat Hukum (Perkembagan dan Dinamika Masalah). ctk Pertama. Bandung. Januari. Refika Aditama. 